\title{
Banana Pseudo-Stem Increases the Water-Holding Capacity of Minced Pork Batter and the Oxidative Stability of Pork Patties
}

\author{
Diego E. Carballo ${ }^{1}\left(\mathbb{D}\right.$, Irma Caro ${ }^{2}$, Cristina Gallego ${ }^{1}$, Ana Rebeca González ${ }^{1,3}$, Francisco Javier Giráldez ${ }^{4}(\mathbb{D}$, \\ Sonia Andrés ${ }^{4}$ and Javier Mateo ${ }^{1, *}$ (i)
}

1 Department of Hygiene and Food Technology, Faculty of Veterinary Medicine, University of León, 24071 León, Spain; diegocarballo2@hotmail.com (D.E.C.); cgallg00@estudiantes.unileon.es (C.G.); rebbeka1196@gmail.com (A.R.G.)

2 Department of Nutrition and Food Science, Faculty of Medicine, University of Valladolid, 47005 Valladolid, Spain; irma.caro@uva.es

3 Comercializadora GONAC SA de CV, Camino Nacional No. 7. Ciudad Industrial Xicohtencati II, Huamantla 90500, Mexico

4 Instituto de Ganadería de Montaña, CSIC-Universidad de León, Finca Marzanas s/n, Grulleros, 24346 León, Spain; j.giraldez@eae.csic.es (F.J.G.); sonia.andres@eae.csic.es (S.A.)

* Correspondence: jmato@unileon.es; Tel.: +34-9872-91247

\section{check for} updates

Citation: Carballo, D.E.; Caro, I.; Gallego, C.; González, A.R.; Giráldez, F.J.; Andrés, S.; Mateo, J. Banana Pseudo-Stem Increases the Water-Holding Capacity of Minced Pork Batter and the Oxidative Stability of Pork Patties. Foods 2021, 10, 2173. https://doi.org/10.3390/ foods10092173

Academic Editor: Juana Fernández-López

Received: 5 August 2021

Accepted: 10 September 2021

Published: 13 September 2021

Publisher's Note: MDPI stays neutral with regard to jurisdictional claims in published maps and institutional affiliations.

Copyright: (C) 2021 by the authors Licensee MDPI, Basel, Switzerland. This article is an open access article distributed under the terms and conditions of the Creative Commons Attribution (CC BY) license (https:// creativecommons.org/licenses/by/ $4.0 /)$.

\begin{abstract}
Banana pseudo-stem (BPS), which is rich in fibre and polyphenols, is a potential functional ingredient for the food industry. In this study, BPS was added at concentrations of 1.5, 3.0, and $4.5 \mathrm{~g} / \mathrm{kg}$ to a minced pork batter to evaluate its performance as a filler and to pork burger patties to evaluate its performance as a natural antioxidant. The effects of BPS were compared with those of carrageenan and ascorbate, which are a conventional binder and antioxidant, respectively. The performance of BPS was similar to that of carrageenan in terms of the cooking yield and texture of the cooked batter. BPS reduced the brightness of fresh patties and appeared to reduce oxidative discolouration during the frozen storage of raw patties. Moreover, BPS reduced the levels of thiobarbituric acid reactive substances (TBARS) during the refrigerated and frozen storage of cooked patties. A greater decrease in TBARS formation was observed with $4.5 \mathrm{~g}$ BPS $/ \mathrm{kg}$ compared with $0.5 \mathrm{~g}$ sodium ascorbate $/ \mathrm{kg}$ during refrigerated storage. In contrast to ascorbate, BPS promoted the presence of lipid-derived volatile compounds induced by thermal breakdown in the headspace of cooked patties. Nonetheless, this effect was reduced as the amount of BPS in the patties increased. In cooked minced meat products, BPS could increase cooking yields and lipid oxidative stability during storage and might result in a more intense flavour.
\end{abstract}

Keywords: discolouration; lipid autoxidation; natural antioxidant; functional food; cooking yield; patty

\section{Introduction}

Meat products are highly susceptible to oxidative changes that limit their shelf life, such as discolouration during the storage of raw meat products or the development of rancid or warmed-over off-flavours during the storage of cooked meat products [1-3]. The use of antioxidants is a well-known and frequently used strategy to control and minimise these oxidative changes. In this context, the meat industry has shown increasing interest in the use of natural antioxidant-rich sources or their extracts, mainly of vegetal origin, which is partly due to a growing consumer preference for additive-free foods [4-7]. Among the multiple sources of natural antioxidants, there is a range of agroindustry by-products with high contents of phenolics and other active ingredients [8-10]. One that is arousing growing interest is banana pseudo-stem (BPS) [11].

Banana, Musa acuminata, is widely produced in humid tropical and subtropical regions in the world. The production of bananas generates a large number of by-products, and among them is BPS. BPS can be incinerated or left in the plantation soil as a waste residue, 
or it can be used as bio-fertiliser or for manufacturing purposes in a variety of industrial areas, from animal feed to the cultivation of edible mushrooms, paper production, or application as a raw material for textiles or cement reinforcement [11-13]. According to Mohapatra, Mishra, and Sutar [14], in India, BPS uses include food preparation, where the pith of BPS is used as an ingredient in flours, jams, drinks, and confectionery products.

As a result of the health-promoting and technological functional properties attributed to BPS, its use as a food supplement or functional food ingredient has been suggested. According to Bhaskar, Mahadevamma, Chilkunda, and Salimath [15], BPS, due to its high content of dietary fibre and polyphenols, could promote beneficial health effects. Its high starch and fibre contents provide the product with high water-holding capacity and thickening and gelling properties, and as a polyphenol-rich material, it can exert antimicrobial and antioxidant effects in food [11,16].

Saravanan and Aradhya [17] stated that BPS is a potential source of natural antioxidants for the food and nutraceutical industry. They reported that BPS contains high levels of polyphenols, such as protocatechuic acid, gallic acid, caffeic acid, ferulic acid, and tannic acid, among others. Furthermore, the scavenging effect provided by an acetone extract of BPS at $100 \mu \mathrm{g} / \mathrm{mL}$ on the 1,1-diphenyl-2-picrylhydrazyl (DPPH) radical was between $41 \%$ and $70 \%$, depending on the cultivar, while the scavenging effect on butylated hydroxytoluene (BHT) under the same conditions was $93 \%$.

Recent studies have investigated the potential of BPS as a natural antioxidant ingredient in foods. Ho, Abdul Aziz, and Azahari [18] used BPS (up to 10\%) mixed with wheat flour to prepare bread. Their results showed that BPS increased the amounts of ash and dietary fibre and provided antioxidant capacity without altering panellist acceptability ratings. Anusuya, Gomathi, Tharani, and Murugesan [19] investigated the effect of BPS in sunflower oil and suggested that BPS extract, rich in polyphenols, could serve as a substitute for synthetic antioxidants in edible oils. However, no studies have reported the use of BPS in the formulation of meat products. In this context, the novelty of this research lies in evaluating the potential of BPS as a functional ingredient in the meat industry. In particular, the filler effect of BPS in cooked meat batter was evaluated and compared with that of carrageenan (CAR), and its antioxidant effect in burger patties was analysed and compared with that of ascorbate.

\section{Materials and Methods}

\subsection{Ingredients}

Fresh boneless pork loins were purchased from a local meat retailer, and food-grade carrageenan (Danagel, FMC ByoPolimer, Brussels, Belgium), sodium ascorbate, sodium chloride, and spices were obtained from local suppliers. Dried powdered BPS was provided by Mfood Alimento Natural (León, Spain). This was obtained from the Canary Islands banana plantations by cutting the pseudo-stem longitudinally, which was then ripened and sun-dried for three weeks, cut, dried with hot air $\left(65^{\circ} \mathrm{C}\right)$, and ground into a powder. The powdered BPS composition characteristics were analysed in duplicate, and the results are shown in Table 1.

Table 1. Composition of banana pseudo-stem (BPS).

\begin{tabular}{cc}
\hline Component & \\
\hline Moisture (\%) $^{1}$ & 10.3 \\
Crude protein (\%) $^{1}$ & 6.8 \\
Ether extract (\%) $^{1}$ & 0.90 \\
Ashes (\%) $^{1}$ & 28.8 \\
\hline
\end{tabular}


Table 1. Cont.

\begin{tabular}{|c|c|}
\hline \multicolumn{2}{|l|}{ Component } \\
\hline Fibre & \\
\hline Total dietary fibre $(\%)^{1}$ & 46.5 \\
\hline Neutral detergent fibre $(\%)^{2}$ & 39.2 \\
\hline Acid detergent fibre $(\%)^{2}$ & 27.4 \\
\hline Total extractable polyphenols (\%) ${ }^{3}$ & 2.32 \\
\hline \multicolumn{2}{|l|}{ Mineral content ${ }^{4}$} \\
\hline Potassium (\%) & 22.1 \\
\hline Phosphorous (\%) & 0.78 \\
\hline Calcium $(\%)$ & 0.40 \\
\hline Magnesium (\%) & 0.31 \\
\hline Sodium $(\%)$ & 0.11 \\
\hline Iron $(\mathrm{mg} / 100 \mathrm{~g})$ & 37.5 \\
\hline Manganese (mg/100 g) & 3.76 \\
\hline Zinc (mg/100 g) & 3.20 \\
\hline Copper (mg/100 g) & 0.95 \\
\hline
\end{tabular}

${ }^{1}$ AOAC [20]. ${ }^{2}$ Van Soest, Robertson, and Lewis [21]. ${ }^{3}$ Extracted in methanol and expressed as gallic acid equivalents; Folin and Ciocalteu [22]. ${ }^{4}$ Osorio et al. [23].

\subsection{Experimental Plan}

This research was composed of two experiments. The first experiment evaluated the performance of BPS as a filler in minced lean-pork batter. BPS was compared with a control (CON) batter (with no filler) and batter with CAR. A total of seven batter mixtures were prepared. Three of them contained BPS at concentrations of $1.5,3.0$, and $4.5 \mathrm{~g} / \mathrm{kg}$ batter, designated as low (LBPS), medium (MBPS), and high (HBPS) levels, respectively. Another was made without fillers (CON), and the other three contained CAR at the same levels as those used for BPS (LCAR, MCAR, and HCAR). The quality traits analysed were the $\mathrm{pH}$ of the raw pork batter, cooking losses, and texture profile analysis of the cooked pork batter. The amounts of BPS and CAR used were within the range reported for meat products for CAR $[24,25]$. Moreover, in a preliminary consumer study $(n=117)$, we found that the use of $4.5 \mathrm{~g}$ BPS $/ \mathrm{kg}$ pork batter did not negatively affect their sensory acceptance as compared with a patty with $4.5 \mathrm{~g} \mathrm{CAR} / \mathrm{kg}$ (the mode value obtained in the sensory test for the BPS patty was 7, and that for the CAR patty was $6, p=0.189$, Mann-Whitney test; unpublished data).

In the second experiment, five types of lean-pork burger patties were prepared. The effect of using BPS (at the above-mentioned LBPS, MBPS, and HBPS levels) on the oxidative stability of the patties was evaluated and compared with a CON patty (with no antioxidants) and a patty containing $0.5 \mathrm{~g} / \mathrm{kg}$ sodium ascorbate (ASC), which is an antioxidant additive commonly used in the meat industry [24]. Colour stability was determined in fresh patties, and the patty colour was compared before and after 3 months of frozen storage. Lipid oxidative stability was determined in cooked patties by evaluating the formation of thiobarbituric acid reactive substances (TBARS) during refrigerated ( 2 days) and frozen (3 months) storage. Finally, headspace volatile components in recently cooked patties were analysed to assess lipid thermal stability to oxidative breakdown.

The pork batter and patties were prepared in the Food Processing Hall of the Veterinary Faculty at the University of León, León (Spain). Raw batter and burger patties were prepared in quintuplicate (five batches or independent replications). Each batch consisted of the following experimental levels: seven types of raw batter for the first experiment and five burger patties for the second.

\subsection{Experiment 1: Preparation of Lean-Pork Patty Batter}

Lean-pork batter samples were prepared in quintuplicate, i.e., on five different days. Patty batter samples were prepared from a $2 \mathrm{~kg} \mathrm{mix}$, made with $78.5 \%$ minced pork loin (butcher's mincer, $5 \mathrm{~mm} 15 \mathrm{~mm}$ diameter sieve), 20\% water, and 1.5\% common salt, which 
were mixed manually for $2 \mathrm{~min}$. Then, seven $250 \mathrm{~g}$ portions were taken from the whole mix and assigned to the corresponding experimental treatments: CON, control (with no added ingredients), LBPS, MBPS, HBPS, LCAR, MCAR, and HCAR (with the addition of the above-mentioned amounts of BPS or carrageenan). Then, each portion with the corresponding ingredient was mixed manually for $2 \mathrm{~min}$. Then, minced lean-pork batter samples ( $35 \pm 1 \mathrm{~g}$ ) were carefully placed in quadruplicate into $50 \mathrm{~mL}$ Falcon tubes, and the then, tubes with the samples were stored in the refrigerator overnight before cooking and analysis.

\subsection{Experiment 1: Evaluation of Water-Holding Capacity and Texture of Cooked Pork Batter}

The pork batter $\mathrm{pH}$ was measured in duplicate using a puncture electrode (CRISON GLP22, Alella, Barcelona, Spain). Cooking losses were determined following the procedure described by Lin and Mei [26], with some modifications. Briefly, the pork batter samples placed in the tubes were cooked at $80^{\circ} \mathrm{C}$ for $30 \mathrm{~min}$ in a water bath (Tectron 3473100 , Barcelona, Spain). After cooking, the tubes were cooled in an ice bath for $10 \mathrm{~min}$, and the cooked meat batter samples were removed from the tubes and then carefully drained and weighed. In addition, following the methods described by Townsend, Witnauer, Riloff, and Swift [27], the drained juice was poured into a flask, weighed, dried at $100 \pm 2{ }^{\circ} \mathrm{C}$ for $4 \mathrm{~h}$, and weighed again in order to estimate the solids content in the juice. Then, the cooked batter samples were cut to obtain three $1 \mathrm{~cm}$ cubes per sample, which were used for texture profile analysis (TPA). Each meat cube was compressed ( $80 \%$ strain value) in two repeated cycles ( $5 \mathrm{~s}$ between each compression) using a texture analyser (TA.XT2i, Stable Micro Systems, Surrey, England) equipped with a $5 \mathrm{~cm}$ diameter cylindrical probe operating at a test speed of $0.5 \mathrm{~m} / \mathrm{s}$. The Texture Expert v1.20 software was used to obtain the hardness, springiness, cohesiveness, and chewiness parameters.

\subsection{Experiment 2: Preparation of Lean-Pork Patties}

A total of $3 \mathrm{~kg}$ of patty batter was prepared in quintuplicate (on five different days) with $78.5 \%$ minced lean ( $5 \mathrm{~mm}$ diameter sieve) pork loin, $20 \%$ water, $1.5 \%$ common salt, and $1 \mathrm{~g} / \mathrm{kg}$ pepper. All of the ingredients were vigorously mixed manually ( $2 \mathrm{~min})$, and the resulting batter was divided into five $0.5 \mathrm{~kg}$ portions. One portion was used for $\mathrm{CON}$ patties with no further ingredient addition; amounts of $1.5,3.0$, and 4.5 of BPS $/ \mathrm{kg}$ were added to three portions (LBPS, MBPS, and HBPS portions, respectively), and $0.5 \mathrm{~g}$ of sodium ascorbate $/ \mathrm{kg}$ was added to the other portion (ASC). The batter was vigorously mixed manually for another $2 \mathrm{~min}$, and four $100 \mathrm{~g}$ patties were formed from each one. Two patties were used for colour stability analysis, and the other two patties were used to analyse the lipid oxidative stability of cooked patties and the headspace volatile composition.

\subsection{Experiment 2: Evaluation of the Colour and Lipid Oxidative Stability of Patties}

Colour was measured immediately, in triplicate, directly on the upper surface of the fresh patties using a Konica Minolta CM-700d colourimeter (Osaka, Japan) operating with D65 illuminant, a visual angle of $10^{\circ}$, and an $11 \mathrm{~mm}$ aperture for illumination and $8 \mathrm{~mm}$ for measurement, in SCI mode. Then, the patties were wrapped in polyvinyl chloride cling film and stored for 90 days at $-18{ }^{\circ} \mathrm{C}$, thawed for $48 \mathrm{~h}$ at $4{ }^{\circ} \mathrm{C}$, unwrapped, and tempered for $2 \mathrm{~h}$ at room temperature $\left(22^{\circ} \mathrm{C}\right)$, and the colour was measured as described before.

For the evaluation of lipid oxidative stability, patties were first cooked in a convection oven for $150{ }^{\circ} \mathrm{C}$ until reaching a core temperature of $70 \pm 2{ }^{\circ} \mathrm{C}$ (for approximately $20 \mathrm{~min}$ ), and then, each patty was divided into two halves. Then, one of the halves was divided into three equal portions: the first was used for immediate analysis of TBARS (TBARS in recently cooked patties), and the second and the third were wrapped individually in polyvinyl chloride cling film: one was stored at $4 \pm 2{ }^{\circ} \mathrm{C}$ in darkness for two days, and the other was stored at $-18{ }^{\circ} \mathrm{C}$ for three months before TBARS analysis. This analysis was carried out in duplicate following the procedure described by Nam and Ahn [28]. The frozen patty portion was thawed at $4{ }^{\circ} \mathrm{C}$ for one day before analysis. 
The remaining halves were used for the analysis of volatile compounds, which was carried out in duplicate by gas chromatography coupled to mass spectrometry following the procedure described by Carballo, Caro, Andrés, Giráldez, and Mateo [29] with modification of the extraction temperature. Briefly, $2 \mathrm{~g}$ of homogenised cooked patty sample was placed in $15 \mathrm{~mL}$ screw-cap vials (Agilent Technologies, Santa Clara, CA, USA), which were then intermittently agitated ( $500 \mathrm{rpm}, 5 \mathrm{~s}$ on, $2 \mathrm{~s}$ off) at $110^{\circ} \mathrm{C}$ for $40 \mathrm{~min}$ in the autosampler. CG 7890A equipment (Agilent Technologies, Santa Clara, FL, USA) was used. The headspace injection volume was $1 \mathrm{~mL}$, and the injector was operated in splitless mode at $260{ }^{\circ} \mathrm{C}$. The syringe needle temperature was $120^{\circ} \mathrm{C}$, and the filling and injection speeds were 50 and $250 \mu \mathrm{L} / \mathrm{s}$, respectively. A DB-5MS column $(60 \mathrm{~m} \times 0.25 \mathrm{~mm}$ ID $\times 0.25 \mu \mathrm{m}$ film thickness; J\&W Scientific, Folsom, CA, USA) was used for separation, and helium at a flow rate of $1.5 \mathrm{~mL} / \mathrm{min}$ was the carrier gas. The oven conditions were as follows: $38^{\circ} \mathrm{C}$ held for $1 \mathrm{~min}$ as the initial temperature, which was increased to $50{ }^{\circ} \mathrm{C}$ at $10^{\circ} \mathrm{C} / \mathrm{min}$, then to $146^{\circ} \mathrm{C}$ at $4{ }^{\circ} \mathrm{C} / \mathrm{min}$, then to $200{ }^{\circ} \mathrm{C}$ at $20^{\circ} \mathrm{C} / \mathrm{min}$, and finally to $250{ }^{\circ} \mathrm{C}$ at $50{ }^{\circ} \mathrm{C} / \mathrm{min}$, which was maintained for $11 \mathrm{~min}$. The transfer-line temperature was $260^{\circ} \mathrm{C}$. For detection, a simple quadrupole mass spectrometer (MSD 5975C, Agilent Technologies) was operated with an electron source temperature of $240^{\circ} \mathrm{C}$, a quadrupole temperature of $190^{\circ} \mathrm{C}$, electron energy and emission currents of $70 \mathrm{eV}$ and $35 \mu \mathrm{A}$, respectively, and a scanner range from 40 to $230 \mathrm{~m} / \mathrm{z}$. Tentative identification of volatile compounds was performed by comparing the spectra of the detected volatile compounds with those in the NIST/EPA/NIH-98 Mass Spectral Database and comparing their linear retention indices, which were calculated from the retention times of a series of n-alkanes (Hydrocarbons/C5-C20; Sigma-Aldrich, St. Louis, MO, USA), with those found in the literature [30-32].

\subsection{Statistical Analysis}

The statistical analysis was performed using SPSS Statistics software (version 26; IBM, Somers, NY, USA). Data were analysed using the general linear model analysis of variance, with treatment (ingredients used) as the fixed factor and batch as a random factor. Comparison between storage times or conditions within treatments were analysed using Student's $t$-test for colour data and ANOVA for TBARS data. In this case, storage condition (non-stored, refrigerated storage, and frozen storage) was used as a fixed factor and batch was used as a random factor. ANOVA was followed by the Tukey test to assess differences between treatments, storage times, or conditions. Pearson correlations between selected variables were also carried out.

\section{Results and Discussion}

\subsection{Experiment 1: Effect of BPS on the Water-Holding Capacity and Texture of Pork Batter}

Table 2 shows the effects of adding BPS or CAR at concentrations up to $4.5 \mathrm{~g} / \mathrm{kg}$ to minced lean-pork batter on yields and texture. The batter $\mathrm{pH}$ increased with the increase in the BPS amount, although the change was lower than $0.1 \mathrm{pH}$ units. In contrast, CAR decreased the batter $\mathrm{pH}$, with these changes also lower than 0.1 , and the extent of the decrease remained unchanged regardless of CAR content. CAR is considered a dietary fibre and is frequently used as a meat binder. Both ingredients reduced the cooking losses to similar degrees, and the reductions were proportional to the amount of the ingredient used. The ingredients also tended to reduce hardness, which was significantly higher in CON batter than in the others, with the exception of LBPS $(p<0.05)$. The solids in the fluid lost during cooking and the elasticity, cohesiveness, and chewiness of cooked batter were not affected by the treatment $(p>0.05)$. 
Table 2. Cooking loss and solids in the fluid lost, both expressed as percentages, and texture profile analysis results in minced lean-pork batter as a function of the amount and type of fibre-rich ingredient used $(n=5)$.

\begin{tabular}{|c|c|c|c|c|c|c|c|c|c|}
\hline & \multirow[b]{2}{*}{$\mathrm{CON}$} & \multicolumn{2}{|c|}{$\mathrm{L}: 1.5 \mathrm{~g} / \mathrm{kg}$} & \multicolumn{2}{|c|}{$\mathrm{M}: 3.0 \mathrm{~g} / \mathrm{kg}$} & \multicolumn{2}{|c|}{$\mathrm{H}: 4.5 \mathrm{~g} / \mathrm{kg}$} & \multirow[b]{2}{*}{ SEM } & \multirow[b]{2}{*}{$p$-Value } \\
\hline & & BPS & CAR & BPS & CAR & BPS & CAR & & \\
\hline $\mathrm{pH}$ & $5.68^{d}$ & $5.70^{\mathrm{c}}$ & $5.65^{\mathrm{e}}$ & $5.73^{b}$ & $5.64 \mathrm{e}$ & $5.76^{a}$ & $5.65^{\mathrm{e}}$ & 0.011 & $* * *$ \\
\hline Cooking loss & $24.7^{\mathrm{a}}$ & $22.6^{\mathrm{ab}}$ & $21.8^{b c}$ & $19.0^{\mathrm{c}}$ & $17.8^{\mathrm{cd}}$ & $17.6^{\mathrm{cd}}$ & $16.0^{\mathrm{d}}$ & 1.26 & $* * *$ \\
\hline Solids & 2.66 & 2.43 & 2.62 & 2.33 & 2.34 & 2.11 & 2.21 & 0.200 & NS \\
\hline Hardness (N) & $234^{\mathrm{a}}$ & $220^{a b}$ & $213^{b c}$ & $219 \mathrm{bc}$ & $218^{b c}$ & $205^{c}$ & $218^{b c}$ & 7.29 & $*$ \\
\hline Elasticity & 0.429 & 0.416 & 0.415 & 0.415 & 0.417 & 0.419 & 0.433 & 0.010 & NS \\
\hline Cohesiveness & 0.736 & 0.786 & 0.788 & 0.785 & 0.741 & 0.764 & 0.753 & 0.027 & NS \\
\hline Chewiness (N) & 73.9 & 72.6 & 69.1 & 72.0 & 67.2 & 65.8 & 70.8 & 4.45 & NS \\
\hline
\end{tabular}

$\mathrm{L}, \mathrm{M}$, and $\mathrm{H}=1.5 \mathrm{~g}, 3.0 \mathrm{~g}$, and $4.5 \mathrm{~g}$ of fibre-rich ingredient per $\mathrm{kg}$ of batter, respectively; $\mathrm{CON}$ = control (no addition of fibre-rich ingredients); $\mathrm{BPS}=$ banana pseudo-stem; $\mathrm{CAR}=$ carrageenan; $\mathrm{SEM}=$ standard error of the mean; $p$-value: $\mathrm{NS}=$ not significant; ${ }^{*} p<0.05$; ${ }^{* * *} p<0.001$. abcde Different superscripts in the same row indicate statistical differences by the Tukey test $(p<0.05)$.

The effect of CAR on cooking yield (water retention) in meat products has been demonstrated in previous studies [33,34]. CAR in cooked minced meat products also contributes to gel formation [25], and thus, it can increase the hardness of the meat batter after cooking. However, according to Ayadi et al. [33], and in agreement with this study, the increase was noticeable at concentrations of $>5 \mathrm{~g} / \mathrm{kg}$, which are higher than those used in this study. BPS, a fibre-rich ingredient, has a high water-holding capacity compared with other dietary fibres, such as oat, rice bran, and even soy flour [16]. Overall, the results of this study show that CAR could be replaced by BPS at levels up to $4.5 \mathrm{~g} / \mathrm{kg}$ in cooked meat products without affecting the technological quality traits studied. Both ingredients improved the cooking yield to similar extents.

\subsection{Experiment 2: The Effect of BPS on Colour and Lipid Oxidative Stability of Burger Patties}

Table 3 shows the effect of using ascorbate and BPS on the colour values $\left(L^{*}, a^{*}, b^{*}\right.$, chroma, and hue angle) of recently prepared and frozen-stored and thawed patties. The addition of BPS resulted in a decreased $\mathrm{L}^{*}$, indicating a darkening effect, in the fresh patties $(p<0.001)$; however, no change in $\mathrm{L}^{*}$ due to BPS was observed in the frozen-stored patties. The other colour values $\left(\mathrm{a}^{*}, \mathrm{~b}^{*}\right.$, chroma, and hue angle) were not significantly affected in either fresh or frozen/thawed patties. The effect of adding fibre-rich ingredients to patties on their colour depends on the amount and the colour of the ingredient used, which is beige-brown in the case of BPS. Other studies have also found that rice bran or hazelnut pellicle addition reduces brightness $\left(\mathrm{L}^{*}\right)$ in meat batter and burgers [35].

In general, patties tend to show discolouration during frozen storage, which, together with rancidity due to lipid oxidation, limits their shelf life. Discolouration due to frozen storage has been attributed to myoglobin autooxidation [35-37]. To retard the formation of metmyoglobin in frozen-stored patties, the use of antioxidants has been suggested [38]. In the present study, discolouration was evidenced in both CON and ASC patties by significant decreases in $\mathrm{a}^{*}$ and chroma and an increase in hue angle during frozen storage [39].

In addition, AMSA [39] proposed the use of two visible spectral calculations to evaluate changes in the redness of raw meat due to variations in either oxymyoglobin or deoxymyoglobin contents and subsequent metmyoglobin formation during storage: the wavelength ratios of reflectance $630 \mathrm{~nm} / 580 \mathrm{~nm}\left(\mathrm{R}_{\lambda 630} / \mathrm{R}_{\lambda 580}\right.$, with higher ratios indicating more redness) and $572 \mathrm{~nm} / 525 \mathrm{~nm}\left(\mathrm{R}_{\lambda 572} / \mathrm{R}_{\lambda 525}\right.$, with higher values indicating more discolouration). Table 3 shows the values of these ratios in fresh patties, as calculated from their colour spectra. The use of BPS in fresh patties led to a decrease in $R_{\lambda 630} / R_{\lambda 580}$ and a subsequent increase in $R_{\lambda 572} / R_{\lambda 525}$, and the changes were directly dependent on the BPS amount used. These changes could be the result of a direct effect of BPS on the light reflectance of patties rather than a particular effect of BPS on the proportions of the three myoglobin chemical forms. After frozen storage, the $R_{\lambda 630} / R_{\lambda 580}$ and $R_{\lambda 572} / R_{\lambda 525}$ values, which significantly differed from those of the fresh patties, were similar between groups. 
Table 3. Colour value and reflectance indexes of recently prepared (fresh) and frozen-stored \# patties as a function of the type and amount of antioxidant used $(n=5)$.

\begin{tabular}{|c|c|c|c|c|c|c|c|}
\hline & $\mathrm{CON}$ & ASC & LBPS & MBPS & HBPS & SEM & $p$-Value \\
\hline \multicolumn{8}{|l|}{$\begin{array}{c}\text { Colour values } \\
L^{*}\end{array}$} \\
\hline Fresh & $47.8^{\mathrm{a}}$ & $47.9^{a}$ & $45.9^{b}$ & $45.0^{\mathrm{c}}$ & $44.1^{\mathrm{d}}$ & 0.224 & $* * *$ \\
\hline $\begin{array}{c}\text { Frozen stored } \\
a^{*}\end{array}$ & 45.8 & 45.9 & 44.5 & 43.5 & 42.3 & 1.073 & NS \\
\hline Fresh & $4.59^{1}$ & $4.64^{1}$ & $4.81^{1}$ & $4.89^{1}$ & $5.12^{1}$ & 0.181 & NS \\
\hline $\begin{array}{c}\text { Frozen stored } \\
\qquad b^{*}\end{array}$ & $2.74^{2}$ & $3.13^{2}$ & $3.28^{2}$ & $3.56^{2}$ & $3.93^{2}$ & 0.292 & NS \\
\hline Fresh & 11.8 & 11.8 & 12.1 & 12.2 & 12.4 & 0.290 & NS \\
\hline $\begin{array}{c}\text { Frozen stored } \\
\text { Chroma }\end{array}$ & 10.3 & 10.4 & 11.0 & 11.3 & 11.6 & 0.383 & NS \\
\hline Fresh & $12.7^{1}$ & $12.7^{1}$ & $13.0^{1}$ & $13.1^{1}$ & $13.5^{1}$ & 0.310 & NS \\
\hline $\begin{array}{c}\text { Frozen stored } \\
\text { Hue angle }\end{array}$ & $10.6^{2}$ & $10.9^{2}$ & $11.5^{2}$ & $11.9^{2}$ & $12.2^{2}$ & 0.389 & NS \\
\hline Fresh & $69.1^{2}$ & $68.7^{2}$ & $68.4^{2}$ & $68.1^{2}$ & $67.6^{2}$ & 0.715 & NS \\
\hline $\begin{array}{l}\text { Frozen stored } \\
\text { Reflectance }\end{array}$ & $\begin{array}{l}75.1^{1} \\
\operatorname{ios}^{\&}\end{array}$ & $73.5^{1}$ & $73.3^{1}$ & $72.3^{1}$ & $71.2^{1}$ & 1.037 & NS \\
\hline $\begin{array}{c}\mathrm{R}_{\lambda 630} / \mathrm{R}_{\lambda 580} \\
\text { Fresh }\end{array}$ & $1.88^{\mathrm{a} 1}$ & $1.91^{\mathrm{a} 1}$ & $1.70^{\mathrm{b} 1}$ & $1.59 \mathrm{bc} 1$ & $1.55^{\mathrm{c} 1}$ & 0.017 & $* * *$ \\
\hline Frozen stored & $1.35^{2}$ & $1.43^{2}$ & $1.34^{2}$ & $1.33^{2}$ & $1.32^{2}$ & 0.027 & NS \\
\hline Decrease $^{\$}$ & $0.529^{a}$ & $0.477^{\mathrm{a}}$ & $0.368^{a b}$ & $0.262^{b}$ & $0.223^{b}$ & 0.017 & $* *$ \\
\hline $\begin{array}{c}\mathrm{R}_{\lambda 572} / \mathrm{R}_{\lambda 525} \\
\text { Fresh }\end{array}$ & $0.875^{2}$ & $0.869^{2}$ & $0.936^{2}$ & $0.985^{2}$ & 1.015 & 0.002 & $* * *$ \\
\hline Frozen stored & $0.998^{1}$ & $0.975^{1}$ & $1.029^{1}$ & $1.048^{1}$ & 1.065 & 0.010 & NS \\
\hline Increase $^{\$}$ & $0.123^{a}$ & $0.105^{\mathrm{a}}$ & $0.092^{a b}$ & $0.063^{b c}$ & $0.050^{\mathrm{c}}$ & 0.002 & $* * *$ \\
\hline
\end{tabular}

\# Patties were stored at $-18{ }^{\circ} \mathrm{C}$ for three months, wrapped in cling film, and thawed before colour measurement $\mathrm{CON}=$ control (no addition of antioxidant ingredient); $\mathrm{ASC}=$ addition of $0.5 \mathrm{~g}$ sodium ascorbate per $\mathrm{kg}$ of patty LBSE, MBSE, and HBSE = addition of $1.5 \mathrm{~g}, 3.0 \mathrm{~g}$, and $4.5 \mathrm{~g}$ of banana pseudo-stem, respectively; SEM = standard error of the mean; $p$-value: NS = not significant; ${ }^{* *} p<0.01 ;{ }^{* * *} p<0.001{ }^{\text {abcd }}$ Different superscripts in the same row indicate statistical differences by the Tukey test $(p<0.05) .{ }^{12}$ Different superscripts in the same column for each characteristic indicate statistical differences by Student's $t$-test $(p<0.05)$. \& Reflectance ratios of selected wavelengths $(\lambda)$ related to meat discolouration during storage [39] and increases or decreases in the ratios due to frozen storage. ${ }^{\$}$ Decrease or increase in the corresponding reflectance ratios due to frozen storage (calculated as the ratio in fresh patties minus the ratio in frozen patties).

Table 3 also shows the changes in $R_{\lambda 630} / R_{\lambda 580}$ and $R_{\lambda 572} / R_{\lambda 525}$ for each group of patties due to frozen storage. These were calculated by subtracting the frozen patties' reflectance ratios from those of the fresh patties. An $R_{\lambda 630} / R_{\lambda 580}$ decrease and an $R_{\lambda 572} / R_{\lambda 525}$ increase were found, which were significantly diminished by the presence of BPS. This finding suggests [39] a lower metmyoglobin formation rate, i.e., lower discolouration during frozen storage in the BPS patties, and thus a protective effect of BPS on myoglobin stability to oxidation.

The values of TBARS in recently cooked patties, in cooked and then refrigerated patties (for $48 \mathrm{~h}$ ), and in frozen-stored raw patties (for three months) are shown in Table 4 . Lipid oxidation occurred during both refrigerated and frozen storage of cooked and raw patties, respectively. Oxidation was more pronounced after two days of refrigerated storage than after three months of frozen storage, which is explained by the exceptionally high lipid oxidation rate in meat substrates after heat treatment [40]. 
Table 4. Thiobarbituric acid reactive substances in recently cooked (not stored), refrigerated, and frozen stored patties ( $\mathrm{mg}$ malondialdehyde $/ \mathrm{kg}$ ) as a function of the type and amount of antioxidant used $(n=5)$.

\begin{tabular}{|c|c|c|c|c|c|c|c|}
\hline & CON & ASC & LBPS & MBPS & HBPS & SEM & $p$-Value \\
\hline Not stored & $0.60^{\text {a3 }}$ & $0.14^{\mathrm{e} 3}$ & $0.44^{b 3}$ & $0.32 \mathrm{c} 3$ & $0.24^{\mathrm{d} 3}$ & 0.022 & $* * *$ \\
\hline Refrigerated stored \& & $2.49^{\text {a1 }}$ & $1.23^{\mathrm{c} 1}$ & $1.99 \mathrm{~b} 1$ & $1.27^{\mathrm{c} 1}$ & $1.02^{\mathrm{d} 1}$ & 0.079 & $* * *$ \\
\hline Frozen stored ${ }^{\#}$ & $1.19^{\mathrm{a} 2}$ & $0.51^{\mathrm{c} 2}$ & $1.31^{\mathrm{a} 2}$ & $1.18^{\mathrm{a} 2}$ & $0.82^{b 2}$ & 0.067 & $* * *$ \\
\hline SEM & 0.075 & 0.037 & 0.054 & 0.054 & 0.076 & & \\
\hline$p$-value & $* * *$ & $* * *$ & $* * *$ & $* *$ & $* *$ & & \\
\hline
\end{tabular}

\& After cooking, patties were stored at $4{ }^{\circ} \mathrm{C}$ for $48 \mathrm{~h}$, wrapped in cling film, before TBARS measurement. ${ }^{\#}$ After cooking, patties were frozen and stored at $-18^{\circ} \mathrm{C}$ for three months, wrapped in cling film, and thawed before TBARS measurement. $\mathrm{CON}=$ control (no addition of antioxidant ingredient); ASC = addition of $0.5 \mathrm{~g}$ sodium ascorbate per $\mathrm{kg}$ of patty; LBSE, MBSE, and HBSE = addition of $1.5 \mathrm{~g}, 3.0 \mathrm{~g}$, and $4.5 \mathrm{~g}$ of banana pseudo-stem, respectively; $\mathrm{SEM}=$ standard error of the mean; $p$-value: ${ }^{* *} p<0.01 ; * * * p<0.001$. abcde Different superscripts in the same row indicate statistical differences by the Tukey test $(p<0.05) .{ }^{123}$ Different superscripts in the same column indicate statistical differences by the Tukey test $(p<0.05)$.

The antioxidant effect of BPS was clearly evidenced by changes in the TBARS contents in the cooked patties; i.e., TBARS contents were significantly lower in BPS-containing patties than in CON cooked patties before storage and after refrigerated and frozen storage. The antioxidant effect of BPS (the TBARS reduction) was directly related to the amount used. For the cooked patties stored in the refrigerator, a better, similar, and worse performance was found with the use of 4.5, 3.0, and $1.5 \mathrm{~g}$ BPS $/ \mathrm{kg}$, respectively, compared with the use of $0.5 \mathrm{~g}$ ascorbate $/ \mathrm{kg}$. For the frozen-stored patties, only BPS at a concentration of $4.5 \mathrm{~g} / \mathrm{kg}$ led to a significant reduction in TBARS as compared with controls, and ascorbate was always more efficient than BPS in retarding TBARS formation.

The antioxidant effect of BPS has been reported in previous studies [16,18]. When used as an ingredient in different foods, it was found that the addition of BPS to wheat flour significantly improved the antioxidant capacity of bread [18]. However, no studies have been carried out on BPS in meat products, so there are no literature values to compare with the present results.

\subsection{Experiment 2: Headspace Volatile Composition in Cooked Patties}

A total of 47 volatile compounds released by the cooked patties to the headspace after $40 \mathrm{~min}$ of incubation at $110^{\circ} \mathrm{C}$ were identified in this study: 10 aliphatic aldehydes, 2 ketones, 4 alcohols, 6 furans, 8 hydrocarbons, 13 terpene compounds, 2 benzene compounds, and 2 sulphur compounds. For brevity, Table 5 includes the data for compounds showing concentrations higher than $4 \mathrm{ng}$ equivalent of hexane $/ \mathrm{mL}$ of headspace in any of the treatments. The aldehydes, ketones, alcohols, furans, and hydrocarbons detected are volatile compounds originating from the thermal breakdown of lipids [41-43]. Thus, they would have been formed mainly during the heating of the patties, and their levels would be related to the oxidative stability of lipids to heat treatment. 
Table 5. Major \& and volatile compounds (ng equivalent of hexanal per $\mathrm{mL}$ of headspace) in the headspace of cooked pork patties as a function of the type and amount of antioxidant used $(n=5)$.

\begin{tabular}{|c|c|c|c|c|c|c|c|c|}
\hline & LRI & CON & ASC & LBPS & MBPS & HBPS & SEM & $p$-Value \\
\hline Aldehydes and ketones & & $369.0^{c}$ & $215.0^{d}$ & $643.5^{a}$ & $542.2^{b}$ & $543.1^{\mathrm{b}}$ & 35.30 & $* * *$ \\
\hline Hexanal & 807 & $237.7^{\mathrm{c}}$ & $134.1^{\mathrm{d}}$ & $424.9^{\mathrm{a}}$ & $360.1^{b}$ & $342.3^{b}$ & 20.76 & $* * *$ \\
\hline 2-Heptanona & 901 & $2.7^{c}$ & $1.0^{\mathrm{d}}$ & $7.0^{\mathrm{a}}$ & $4.7^{b}$ & $3.8^{\mathrm{bc}}$ & 0.41 & $* *$ \\
\hline Heptanal & 907 & $32.7^{\mathrm{c}}$ & $20.9^{d}$ & $53.7^{\mathrm{a}}$ & $46.1^{b}$ & $46.55^{\mathrm{ab}}$ & 3.83 & * \\
\hline Octanal & 1007 & $23.8^{c}$ & $12.5^{\mathrm{d}}$ & $47.1^{\mathrm{a}}$ & $35.5^{b}$ & $39.4^{\mathrm{ab}}$ & 4.19 & $*$ \\
\hline 2-Octenal & 1078 & 1.2 & 1.4 & 2.7 & 2.1 & 2.6 & 0.32 & NS \\
\hline Nonanal & 1108 & $64.5^{b}$ & $41.8^{\mathrm{c}}$ & $98.7^{\mathrm{a}}$ & $84.8^{\mathrm{a}}$ & $96.2^{\mathrm{a}}$ & 6.05 & $* *$ \\
\hline Methyl-2-nonenal & 1226 & $2.7^{\mathrm{b}}$ & $1.9^{\mathrm{c}}$ & $3.4^{\mathrm{ab}}$ & $3.1^{\mathrm{ab}}$ & $3.8^{\mathrm{a}}$ & 0.23 & $*$ \\
\hline 2-Decenal & 1287 & 0.9 & 0.4 & 2.3 & 2.6 & 4.2 & 0.46 & NS \\
\hline Alcohols & & 23.3 & 8.5 & 33.1 & 28.7 & 33.1 & 3.09 & NS \\
\hline Pentanol & 770 & 13.5 & 4.8 & 19.4 & 15.9 & 19.0 & 1.72 & NS \\
\hline Octanol & 1087 & 9.3 & 3.7 & 12.5 & 11.0 & 11.9 & 1.26 & NS \\
\hline Furans & & $161.7^{\mathrm{c}}$ & $95.1^{\mathrm{d}}$ & $250.7^{\mathrm{a}}$ & $202.3^{b}$ & $204.0^{b}$ & 13.52 & $* *$ \\
\hline 2-Butylfuran & 893 & $3.2^{\mathrm{a}}$ & $1.7^{\mathrm{b}}$ & $4.0^{\mathrm{a}}$ & $3.8^{\mathrm{a}}$ & $3.0^{\mathrm{a}}$ & 0.28 & * \\
\hline 2-Pentyl & 989 & $151.6^{c}$ & $89.3^{d}$ & $235.5^{\mathrm{a}}$ & $188.2^{b c}$ & $190.6^{b}$ & 12.35 & $* *$ \\
\hline 2-Hexylfuran & 1091 & 2.6 & 1.5 & 3.9 & 3.8 & 3.8 & 0.39 & NS \\
\hline 2-Heptylfuran & 1203 & $1.9^{\mathrm{b}}$ & $0.8^{\mathrm{c}}$ & $2.7^{\mathrm{a}}$ & $2.3^{\mathrm{ab}}$ & $2.9^{a}$ & 0.25 & $*$ \\
\hline Aliphatic hydrocarbons & & $18.6^{\mathrm{b}}$ & $11.0^{\mathrm{c}}$ & $24.2^{\mathrm{a}}$ & $20.8^{a b}$ & $23.2^{\mathrm{a}}$ & 1.73 & * \\
\hline Octane & 800 & $11.4^{\mathrm{b}}$ & $6.0^{c}$ & $15.1^{\mathrm{a}}$ & $13.5^{\mathrm{ab}}$ & $14.8^{\mathrm{ab}}$ & 1.18 & $*$ \\
\hline Terpene compounds & & 300.1 & 280.5 & 269.0 & 239.5 & 255.1 & 8.47 & NS \\
\hline$\alpha$-Pinene & 932 & 30.5 & 32.9 & 28.7 & 23.7 & 26.8 & 1.58 & NS \\
\hline Camphene & 953 & $4.6^{\mathrm{a}}$ & $3.5^{b}$ & $3.6^{\mathrm{b}}$ & $3.2^{b}$ & $3.4^{b}$ & 0.16 & $*$ \\
\hline$\beta$-Pinene & 986 & 27.1 & 24.4 & 23.7 & 20.6 & 21.8 & 0.77 & NS \\
\hline Myrcene & 991 & 7.0 & 7.7 & 6.3 & 5.6 & 6.3 & 0.26 & NS \\
\hline$\alpha$-Phellandrene & 993 & 3.7 & 7.1 & 2.9 & 3.7 & 3.3 & 1.06 & NS \\
\hline$\delta$-Carene & 1008 & 119.4 & 108.5 & 103.2 & 97.7 & 100.0 & 3.50 & NS \\
\hline p-Cymene & 1026 & 12.7 & 8.2 & 10.6 & 10.1 & 11.1 & 0.52 & NS \\
\hline Limonene & 1028 & 85.5 & 78.3 & 78.6 & 66.6 & 74.1 & 2.36 & NS \\
\hline$\beta$-Caryophyllene & 1447 & $4.5^{b}$ & $6.0^{\mathrm{a}}$ & $3.9^{\mathrm{b}}$ & $3.5^{b}$ & $3.6^{b}$ & 0.22 & $* *$ \\
\hline Sulphur compounds & & $7.7^{a b}$ & $5.6^{b}$ & $10.3^{\mathrm{a}}$ & $8.9^{\mathrm{a}}$ & $8.7^{\mathrm{a}}$ & 0.48 & * \\
\hline Dimethyl disulphide & 755 & $7.5^{\mathrm{ab}}$ & $5.6^{\mathrm{b}}$ & $9.8^{\mathrm{a}}$ & $8.4^{\mathrm{a}}$ & $8.4^{\mathrm{a}}$ & 0.45 & * \\
\hline Total sum of volatiles & & $883.9^{\mathrm{c}}$ & $618.2^{d}$ & $1234.9^{\mathrm{a}}$ & $1045.9^{b}$ & $1071.0^{\mathrm{b}}$ & 54.14 & $* *$ \\
\hline
\end{tabular}

\& Only compounds showing $>4 \mathrm{ng}$ equivalent of hexanal $/ \mathrm{mL}$ of headspace in any of the treatments are included. LRI $=$ linear retention index; $\mathrm{CON}=$ control (no addition of antioxidant ingredient); ASC = addition of $0.5 \mathrm{~g}$ sodium ascorbate per kg of patty; LBSE, MBSE, and HBSE = addition of $1.5 \mathrm{~g}, 3.0 \mathrm{~g}$, and $4.5 \mathrm{~g}$ of banana pseudo-stem, respectively; SEM = standard error of the mean; $p$-value: ${ }^{*} p<0.05 ;{ }^{* *} p<0.01 ;{ }^{* * *} p<0.001$. abcd Different superscripts in the same row indicate statistical differences by the Tukey test $(p<0.05)$.

Most of the lipid-derived compounds and the total sum of volatiles were significantly affected by antioxidant treatment. On the one hand, the use of ascorbate resulted in the lowest levels of these volatiles in the patty headspace. This suggests that ascorbate has a protective effect on lipids against their thermal breakdown. In agreement with these results, other studies have found that the use of antioxidants, such as ascorbate, rosemary extract, or astaxanthin in cooked patties, minced meat, or meat models, exerted a suppressive effect on the formation of lipid-derived volatile compounds as compared with controls [29,44].

In contrast, the use of BPS, despite its ability to promote lipid oxidative stability in the patties during storage (Table 3), resulted in a higher concentration of lipid-derived volatile compounds in the patty headspace (presumably originated by thermal breakdown) compared with CON. The effect of BPS on the concentration of these volatile compounds was not proportional to the amount used. On the contrary, the increasing effect of BPS tended to weaken as the amount of BPS was increased (from 1.5 to $4.5 \mathrm{~g} / \mathrm{kg}$ patty). This trend suggests a balance between the protective and pro-oxidative effects of BPS compounds on thermal lipid breakdown.

Two types of mechanisms might be involved in the above-mentioned complex effect of BPS on the presence of lipid-derived volatile compounds in the patty headspace. One of 
them could be associated with changes in the patty matrix structure due to the presence of BPS, which would affect the release of these flavour compounds to the headspace. The other could be related to chemical interactions between specific BPS compounds and the meat lipids, which would affect the lipid thermal breakdown rate during patty heating.

The changes in the patty matrix structure might be attributed to the slight changes in $\mathrm{pH}$ produced by BPS (Table 2) and also to the interaction of minerals from BPS, especially those forming soluble salts, such as $\mathrm{CaCl}_{2}$ or $\mathrm{MgCl}_{2}$, with meat proteins. Changes in the protein matrix affect their ability to bind lipid-derived volatile compounds [45], which, in this case, would be reduced. On the other hand, the transition metals (e.g., iron) incorporated in the patties by BPS might have exerted a catalysing effect on lipid thermal breakdown reactions [46] during patty heating, which would have been more potent than the protective effect of BPS antioxidant compounds. Nonetheless, in contrast, considering the TBARS results (Table 4), the catalysing effect of these metals on lipid oxidation in cooked patties during storage was weaker than the protective effect of BPS antioxidant compounds.

The effect of antioxidant treatment on other volatile compounds was considerably weaker than that described for lipid-derived compounds. Terpene compounds were scarcely affected by antioxidant treatment. Only camphene and caryophyllene contents showed significant differences. The former was higher in CON patties, and the latter was higher in ASC samples. Dimethyl sulphide was also affected, with higher concentrations in BPS than in ASC patties.

Changes in the lipid-derived compounds of the patty headspace resulting from ASC and BPS addition can influence patty flavour perception. The volatile compounds affected by antioxidant treatments generally have a relevant impact on cooked meat flavour [47], either directly in their original forms or as reactive intermediaries in the Maillard reaction [42]. The flavour of ASC patties may be milder, and that of BPS may be more intense. However, further sensory analysis is needed to confirm this hypothesis and to eventually evaluate the effect on consumers' preferences.

\section{Conclusions}

The use of BPS improved the cooking yield of minced lean-pork batter to a similar extent to carrageenan, the conventional binder. In burger patties, the use of BPS seemed to prevent the discolouration of frozen-stored raw patties and diminish the lipid oxidation of cooked patties during refrigerated storage. The antioxidant effect of BPS at a concentration of $4.5 \mathrm{~g} \mathrm{BPS} / \mathrm{kg}$ may be comparable to the use of $0.5 \mathrm{~g}$ sodium ascorbate $/ \mathrm{kg}$ (a conventional antioxidant at its typical amount in meat products). In contrast to ASC, the use of BPS increased the volatile compounds released by the patties due to heat treatment; however, this effect was reduced as the BPS amount was increased. The higher concentration of volatile compounds in the headspace of BPS burger patties would probably result in a change in flavour. Further research is needed to better understand the promoting effect of BPS on the release of volatile compounds and to assess whether this effect, together with the mouthfeel effect of BPS, could improve burger patty flavour perception. BPS is a potential functional ingredient for meat products that, in addition to improving their nutritional value, increases the water-holding capacity and oxidative stability of cooked meat products.

Author Contributions: Conceptualisation, J.M. and I.C.; methodology, D.E.C., I.C. and J.M.; formal analysis, D.E.C., C.G., A.R.G. and J.M.; investigation, D.E.C., C.G., A.R.G. and J.M.; resources, S.A., F.J.G. and J.M.; writing — original draft preparation, D.E.C., I.C. and J.M.; writing-review and editing, D.E.C., J.M., S.A. and F.J.G.; visualisation, J.M.; supervision, I.C. and J.M. All authors have read and agreed to the published version of the manuscript.

Funding: D.E. Carballo is grateful for a doctoral grant from CONACYT (MEX/Ref. 288189).

Institutional Review Board Statement: Not applicable.

Data Availability Statement: The data presented in this study are available on request from the corresponding author. 
Acknowledgments: We acknowledge Juan José del Cano for providing us with the powdered banana pseudo-stem.

Conflicts of Interest: None of the authors has a financial or personal relationship with other people/organisations that could inappropriately influence or bias the paper or present other types of conflict interest. There is no relationship or potential conflicts between the company where Ana Rebeca González is working (Comercializadora GONAC SA de CV) and the research presented in this manuscript.

\section{References}

1. Bekhit, A.E.D.; Geesink, G.H.; Ilian, M.A.; Morton, J.D.; Bickerstaffe, R. The effects of natural antioxidants on oxidative processes and metmyoglobin reducing activity in beef patties. Food Chem. 2003, 81, 175-187. [CrossRef]

2. Falowo, A.B.; Fayemi, P.O.; Muchenje, V. Natural antioxidants against lipid-protein oxidative deterioration in meat and meat products: A review. Food Res. Int. 2014, 64, 171-181. [CrossRef]

3. Shahidi, F. Oxidative stability and shelf life of meat and meat products. In Oxidative Stability and Shelf Life of Foods Containing Oils and Fats; Hu, M., Jacobsen, C., Eds.; Academic Press: New York, NY, USA, 2016; pp. 373-389, ISBN 9781630670566.

4. Jiang, J.; Xiong, Y.L. Natural antioxidants as food and feed additives to promote health benefits and quality of meat products: A review. Meat Sci. 2016, 120, 107-117. [CrossRef]

5. Kumar, Y.; Yadav, D.N.; Ahmad, T.; Narsaiah, K. Recent trends in the use of natural antioxidants for meat and meat products. Compr. Rev. Food Sci. Food Saf. 2015, 14, 796-812. [CrossRef]

6. Lorenzo, J.M.; Pateiro, M.; Domínguez, R.; Barba, F.J.; Putnik, P.; Kovačević, D.B.; Shpigelman, A.; Granato, D.; Franco, D. Berries extracts as natural antioxidants in meat products: A review. Food Res. Int. 2018, 106, 1095-1104. [CrossRef]

7. Shah, M.A.; Bosco, S.J.D.; Mir, S.A. Plant extracts as natural antioxidants in meat and meat products. Meat Sci. 2014, 98, 21-33. [CrossRef] [PubMed]

8. Balasundram, N.; Sundram, K.; Samman, S. Phenolic compounds in plants and agri-industrial by-products: Antioxidant activity, occurrence, and potential uses. Food Chem. 2006, 99, 191-203. [CrossRef]

9. Fava, F.; Zanaroli, G.; Vannini, L.; Guerzoni, E.; Bordoni, A.; Viaggi, D.; Robertson, J.; Waldron, K.; Bald, C.; Esturo, A.; et al. New advances in the integrated management of food processing by-products in Europe: Sustainable exploitation of fruit and cereal processing by-products with the production of new food products (NAMASTE EU). New Biotechnol. 2013, 30, 647-655. [CrossRef]

10. Kammerer, D.R.; Kammerer, J.; Valet, R.; Carle, R. Recovery of polyphenols from the by-products of plant food processing and application as valuable food ingredients. Food Res. Int. 2014, 65, 2-12. [CrossRef]

11. Padam, B.S.; Tin, H.S.; Chye, F.Y.; Abdullah, M.I. Banana by-products: An under-utilized renewable food biomass with great potential. J. Food Sci. Technol. 2014, 51, 3527-3545. [CrossRef] [PubMed]

12. Cordeiro, N.; Belgacem, M.N.; Torres, I.C.; Moura, J.C.V.P. Chemical composition and pulping of banana pseudo-stems. Ind. Crops Prod. 2004, 19, 147-154. [CrossRef]

13. Li, K.; Fu, S.; Zhan, H.; Zhan, Y.; Lucia, L.A. Analysis of the chemical composition and morphological structure of banana pseudo-stem. BioResources 2010, 5, 576-585.

14. Mohapatra, D.; Mishra, S.; Sutar, N. Banana and its by-product utilisation: An overview. Sci. Ind. Res. 2010, 69, 323-329.

15. Bhaskar, J.J.; Mahadevamma, S.; Chilkunda, N.D.; Salimath, P.V. Banana (Musa sp. var. elakki bale) flower and pseudostem: Dietary fiber and associated antioxidant capacity. J. Agric. Food Chem. 2012, 60, 427-432. [CrossRef] [PubMed]

16. Aziz, N.A.A.; Ho, L.H.; Azahari, B.; Bhat, R.; Cheng, L.H.; Ibrahim, M.N.M. Chemical and functional properties of the native banana (Musa acuminata $\times$ balbisiana Colla cv. Awak) pseudo-stem and pseudo-stem tender core flours. Food Chem. 2011, 128, 748-753. [CrossRef]

17. Saravanan, K.; Aradhya, S.M. Polyphenols of pseudostem of different banana cultivars and their antioxidant activities. J. Agric. Food Chem. 2011, 59, 3613-3623. [CrossRef] [PubMed]

18. Ho, L.H.; Abdul Aziz, N.A.; Azahari, B. Physico-chemical characteristics and sensory evaluation of wheat bread partially substituted with banana (Musa acuminata $\times$ balbisiana cv. Awak) pseudo-stem flour. Food Chem. 2013, 139, 532-539. [CrossRef]

19. Anusuya, N.; Gomathi, R.; Tharani, J.; Murugesan, G.S. Impact of polyphenols from banana pseudostem on sunflower oil stability. Food Sci. Biotechnol. 2013, 22, 773-780. [CrossRef]

20. AOAC. Official Methods of Analysis of the Association of Official's Analytical Chemists, 17th ed.; AOAC: Arlington, TX, USA, 2003.

21. Van Soest, P.J.; Robertson, J.B.; Lewis, B.A. Methods for dietary fiber, neutral detergent fiber, and nonstarch polysaccharides in relation to animal nutrition. J. Dairy Sci. 1991, 74, 3583-3597. [CrossRef]

22. Folin, O.; Ciocalteu, V. On tyrosine and tryptophane determinations in proteins. J. Biol. Chem. 1927, 73, 627-650. [CrossRef]

23. Osorio, M.T.; Zumalacárregui, J.M.; Bermejo, B.; Lozano, A.; Figueira, A.C.; Mateo, J. Effect of ewe's milk versus milk-replacer rearing on mineral composition of suckling lamb meat and liver. Small Rumin. Res. 2007, 68, 296-302. [CrossRef]

24. Feiner, G. Fresh sausages. In Meat Products Handbook: Practical Science and Technology; Woodhead Publishing: Cambridge, UK, 2006; pp. 297-309.

25. Trius, A.; Sebranek, J.G. Carrageenans and their use in meat products. Crit. Rev. Food Sci. Nutr. 1996, 36, 69-85. [CrossRef]

26. Lin, K.-W.; Mei, M.-Y. Influences of gums, soy protein isolate, and heating temperatures on reduced-fat meat batters in a model system. J. Food Sci. 2000, 65, 48-52. [CrossRef] 
27. Townsend, W.; Witnauer, L.; Riloff, J.; Swift, C. Comminuted meat emulsions: Differential thermal analysis of fat transition. Food Technol. 1968, 22, 319.

28. Nam, K.C.; Ahn, D.U. Use of antioxidants to reduce lipid oxidation and off-odor volatiles of irradiated pork homogenates and patties. Meat Sci. 2003, 63, 1-8. [CrossRef]

29. Carballo, D.E.; Caro, I.; Andrés, S.; Giráldez, F.J.; Mateo, J. Assessment of the antioxidant effect of astaxanthin in fresh, frozen and cooked lamb patties. Food Res. Int. 2018, 111, 342-350. [CrossRef]

30. Dosoky, N.S.; Satyal, P.; Barata, L.M.; Da Silva, J.K.R.; Setzer, W.N. Volatiles of black pepper fruits (Piper nigrum L.). Molecules 2019, 24, 4244. [CrossRef] [PubMed]

31. Kondjoyan, N.; Berdagué, J.-L. A Compilation of Relative Retention Indices for the Analysis of Aromatic Compounds; Laboratoire Flaveur, Institut National de la Reserche Agronomique: Theix, France, 1996.

32. Linstrom, P.J.; Mallard, W.G. NIST Chemistry WebBook, NIST Standard Reference Database Number 69; National Institute of Standards and Technology: Gaithersburg, MD, USA, 2020; p. 20899. Available online: https://webbook.nist.gov/chemistry/ (accessed on 10 January 2021).

33. Ayadi, M.A.; Kechaou, A.; Makni, I.; Attia, H. Influence of carrageenan addition on turkey meat sausages properties. J. Food Eng. 2009, 93, 278-283. [CrossRef]

34. Pietrasik, Z. Binding and textural properties of beef gels processed with $\mathrm{K}$-carrageenan, egg albumin and microbial transglutaminase. Meat Sci. 2003, 63, 317-324. [CrossRef]

35. Leygonie, C.; Britz, T.J.; Hoffman, L.C. Impact of freezing and thawing on the quality of meat: Review. Meat Sci. 2012, 91, 93-98. [CrossRef] [PubMed]

36. Mancini, R.A.; Hunt, M.C. Current research in meat color. Meat Sci. 2005, 71, 100-121. [CrossRef] [PubMed]

37. Quevedo, R.; Pedreschi, F.; Valencia, E.; Díaz, O.; Bastías, J.; Muñoz, O. Kinetic modelling of deterioration of frozen industrial burgers based on oxidative rancidity and color. J. Food Process. Preserv. 2018, 42, e13655. [CrossRef]

38. Akarpat, A.; Turhan, S.; Ustun, N.S. Effects of hot-water extracts from myrtle, rosemary, nettle and lemon balm leaves on lipid oxidation and color of beef patties during frozen storage. J. Food Process. Preserv. 2008, 32, 117-132. [CrossRef]

39. AMSA. Guidelines for Meat Color Evaluation; American Meat Science Association: Champaign, IL, USA, 2012; Available online: https:/ / meatscience.org/docs/default-source/publications-resources/hot-topics/2012_12_meat_clr_guide.pdf?sfvrsn= d818b8b3_0 (accessed on 31 August 2021).

40. Min, B.; Ahn, D.U. Mechanism of lipid peroxidation in meat and meat products-A review. Food Sci. Biotechnol. 2005, 14, 152-163.

41. Resconi, V.; Escudero, A.; Campo, M. The Development of Aromas in Ruminant Meat. Molecules 2013, 18, 6748-6781. [CrossRef] [PubMed]

42. Shahidi, F.; Oh, W.Y. Lipid-derived flavor and off-flavor of traditional and functional foods: An overview. J. Food Bioact. 2020, 10. [CrossRef]

43. Wang, R.; Huang, F.; Zhang, L.; Liu, Q.; Zhang, C.; Zhang, H. Changes in the texture, microstructures, colour and volatile compounds of pork meat loins during superheated steam cooking. Int. J. Food Sci. Technol. 2019, 54, 2821-2830. [CrossRef]

44. Kim, H.W.; Miller, D.K.; Lee, Y.J.; Kim, Y.H.B. Effects of soy hull pectin and insoluble fiber on physicochemical and oxidative characteristics of fresh and frozen/thawed beef patties. Meat Sci. 2016, 117, 63-67. [CrossRef]

45. Pérez-Juan, M.; Flores, M.; Toldrá, F. Effect of pork meat proteins on the binding of volatile compounds. Food Chem. 2008, 108, 1226-1233. [CrossRef]

46. Shahidi, F. Lipid-derived flavors in meat products. In Meat Processing: Improving Quality; Kerry, J.P., Kerry, J.F., Ledward, D.A., Eds.; Woodhead Publishing: Cambridge, UK, 2002; pp. 105-122.

47. Aaslyng, M.D.; Meinert, L. Meat flavour in pork and beef-From animal to meal. Meat Sci. 2017, 132, 112-117. [CrossRef] 